\section{KEEFEKTIFAN PENERAPAN KOMBINASI MODEL KOOPERATIF TIPE TGT DAN TIPE NHT}

\section{PUTRIYANI S.}

Email:putriyani49@gmail.com

STKIP Muhammadiyah Enrekang, Enrekang, Indonesia

\begin{tabular}{|c|c|}
\hline Keyword & Abstrak \\
\hline $\begin{array}{l}\text { Effectiveness, } \\
\text { TGT, NHT }\end{array}$ & $\begin{array}{l}\text { This is a pre experimental research which aims were determine the effectiveness of } \\
\text { learning mathematics through application of TGT and NHT cooperative models } \\
\text { combination which includes: (1) students' activities, (2) teacher's activity in } \\
\text { managing learning, (3) students' responses, and (4) mathematics learning student's } \\
\text { achievement after the application of TGT and NHT cooperative models combination. } \\
\text { Population is XII IA students at the first semester of academic year 2016/2017. The } \\
\text { sample was } 28 \text { students taken through random cluster sampling technique. The results } \\
\text { showed that: (1) students' learning activities was good category; (2) the ability of } \\
\text { teachers to manage learning was very good category; (3) students responded } \\
\text { positively to the learning; and (4) the learning outcomes of after being taught by a } \\
\text { combination of TGT and NHT cooperative models achieved } 96,43 \% \text { and the mean } \\
\text { score is } 83,04 \text { with a standard deviation of } 9,75 \text {. }\end{array}$ \\
\hline
\end{tabular}

Keefektifan,

\begin{tabular}{l}
\hline Abstrak \\
\hline Jenis penelitian adalah pra eksprimen yang bertujuan untuk mengetahui keefektifan \\
penerapan kombinasi model kooperatif tipe TGT dan tipe NHT meliputi: (1) aktivitas \\
siswa, (2) aktivitas guru mengelola pembelajaran, (3) respon siswa, dan (4) \\
pencapaian prestasi belajar matematika siswa setelah penerapan kombinasi kooperatif \\
tipe TGT dan tipe NHT. Populasi penelitian adalah siswa kelas XII IA semester ganjil \\
tahun pelajaran 2016/2017. Sampel sebanyak 28 orang siswa dipilih dengan teknik \\
cluster random sampling. Hasil penelitian menunjukkan bahwa: (1) aktivitas siswa \\
terhadap pembelajaran kombinasi model kooperatif tipe TGT dan tipe NHT berada \\
pada kategori baik, (2) kemampuan guru mengelola pembelajaran berada dalam \\
kategori sangat baik, (3) siswa memberikan respons positif terhadap pembelajaran, \\
dan (4) hasil belajar siswa setelah diajar dengan kombinasi model kooperatif tipe TGT \\
dan tipe NHT mencapai ketuntasan belajar $96,43 \%$ dengan nilai rata-rata 83,04 dan \\
standar deviasi 10,04.
\end{tabular}

\#\# HowToCite\#\#

S. Putriyani (2017). Keefektifan Penerapan Kombinasi Model Kooperatif Tipe TGT dan Tipe NHT. Edumaspul Jurnal Pendidikan, 1(2), 24-35 


\section{PENDAHULUAN}

Berbagai upaya yang telah ditempuh
untuk meningkatkan kualitas pembelajaran, antara lain: pembaharuan dalam kurikulum, pengembangan model pembelajaran, perubahan sistem penilaian, dan lain sebagainya. Salah satu unsur yang sering dikaji dalam hubungannya dengan keaktifan dan hasil belajar siswa adalah usaha meningkatkan kemampuan guru dalam belajar-mengajar. Salah satu

guru adalah mengusahakan suasana kelas selama pembelajaran berlangsung berada pada kondisi yang menyenangkan dan menarik perhatian siswa. Namun berdasarkan pengalaman, masih rendahnya partisipasi siswa untuk ikut berperan aktif pada saat pembelajaran berlangsung. Padahal keaktifan siswa dalam pembelajaran merupakan salah satu hal penting dalam pembelajaran.Ada beberapa siswa yang kurang antusias, masih pasif, enggan, takut, dan malu untuk bertanya.Mereka memilih diam jika ada suatu hal yang belum mereka pahami dari pada harus bertanya kepada guru yang mengajar. Menurut beberapa orang siswa, hal ini disebabkan karena mereka tidak berani bertanya kepada guru, takut salah dan lebih senang bertanya kepada teman. Keadaan tersebut apabila didiamkan akan menyebabkan siswa semakin mengalami kesulitan dalam memepelajari dan memahami konsep-konsep berikutnya.

Salah satu penyebab rendahnya partisipasi aktif siswa adalah pemilihan model pembelajaran yang kurang tepat. Untuk mengatasi masalah tersebut diperlukan model pembelajaran yang berpusat pada siswa (Bas dan Beyhan, 2010: 366). Khusus pembelajaran matematika, guru sebaiknya menggunakan model yang memberi kesempatan kepada siswa untuk aktif berdiskusi menemukan pemecahan masalah matematika yang dipelajari (Goos, 2004: 259). Hasil penelitian
Walmsley dan Muniz (2003) dalam Solikhah (2014: 729) menyatakan model pembelajaran kooperatif mempunyai banyak efek yang positif dalam pembelajaran matematika apabila diterapkan dengan tepat. Hasil tersebut sejalan dengan penelitian yang menyimpulkan pembelajaran kooperatif bermanfaat untuk meningkatkan partisipasi siswa dalam memahami materi (SmithStoner \& Molle, 2010) dan juga mengembangkan kemampuan umum para siswa (Ballantine \& Larres, 2007). Beberapa hasil penelitian menyimpulkan bahwa pembelajaran kooperatif secara signifikan menghasilkan prestasi lebih baik daripada menggunakan pembelajaran tradisional (Doymus, 2007; Adeyemi, 2008).

Model pembelajaran kooperatif antara lain Team Games Tournament (TGT) dan Numbered Heads Together (NHT). Charlton, Williams dan McLaughlin (2005: 66-72) mengemukakan bahwa pembelajaran dengan games dapat membuat siswa lebih aktif dan merasa senang untuk belajar. Pembelajaran tersebut terlihat menarik ketika penjelasan guru dikombinasikan dengan games sehingga penyampaian materi menjadi lebih cepat tersampaikan.

TGT merupakan salah satu tipe model pembelajaran kooperatif yang menggunakan turnamen akademik, kuiskuis dan sistem skor kemajuan individu, dimana para siswa berlomba sebagai wakil tim mereka dengan anggota tim lain yang kinerja akademik sebelumnya setara seperti mereka (Slavin, 2008: 164).

Purnamasari (2013:

menyimpulkan dalam penelitiannya bahwa kemampuan koneksi matematika, kemampuan penalaran, dan kemandirian belajar siswa yang mengikuti pembelajaran kooperatif tipe TGT lebih baik dibandingkan siswa yang diajar menggunakan model pembelajaran langsung. Hal ini sejalan dengan penelitian 
Annurwanda, Mardiyana, dan Saputro (2014) yang melakukan eksperimentasi model pembelajaran kooperatif tipe TGT dan TAI. Diperoleh hasil yaitu prestasi belajar matematika siswa yang dikenai model pembelajaran TGT lebih baik daripada prestasi belajar matematika siswa yang dikenai model pembelajaran TAI dan model pembelajaran langsung. Selain itu Lai,et al.(2012) menemukan bahwa ketika siswa bermain game, mereka dapat lebih fokus pada kegiatan pembelajaran kooperatif dan ingin menang. Sepanjang siswa bermain game, mereka akan tertarik pada isi kursus dan meningkatkan motivasi diri dan prestasi belajar mereka.

Slavin (2008:163) menjelaskan bahwa secara umum TGT sama saja dengan STAD kecuali satu hal: TGT menggunakan turnamen akademik, dan menggunakan kuis-kuis dan sistem skor kemajuan individu, di mana para siswa berlomba sebagai Menurut Kahfi (2004:9) pembelajaran kooperatif tipe TGT meliputi 2 tahap. Yaitu pra kegiatan pembelajaran dan detail kegiatan pembelajaran. Pra kegiatan pembelajaran meliputi penyajian materi, membagi siswa dalam kelompok belajar, dan membagi siswa pada meja turnamen. Detail kegiatan pembelajaran meliputi: (1) mengajar (teach), (2) belajar kelompok (team teach), (3) permainan (tournament).

Menurut Nur (2005:78) dalam Rahmi (2008:87) metode pembelajaran NHT menjamin keterlibatan total semua siswa dan merupakan upaya yang sangat baik untuk meningkatkan tanggung jawab individu dalam diskusi kelompok. Metode NHT ini menekankan siswa untuk saling bekerja sama dalam kelompok, sehingga masing-masing anggota kelompok paham dengan hasil kerja kelompoknya dan bertanggung jawab terhadap hasil diskusinya, dengan sendirinya siswa merasa dirinya harus terlibat aktif dalam proses pembelajaran.
Hasil penelitian Fuad (2009) menunjukkan bahwa model pembelajaran NHT dapat meningkatkan motivasi dan hasil belajar matematika siswa kelas VIIIA. Selain itu, Irianda dan Tanjung (2010) menemukan bahwa prestasi belajar siswa kelas XI IPA mengalami peningkatan setelah diajar menggunakan model pembelajaran NHT. Dalam penelitian ini, tahap pembelajaran kooperatif tipe NHT yang dapat meningkatkan prestasi belajar siswa yaitu pada tahap penomoran (numbering). siswa dibagi dalam kelompok-kelompok yang heterogen yang beranggotakan 4-5 siswa berdasarkan nilai ulangan harian siswa kemudian siswa diberi nomor-nomor sesuai dengan jumlah anggota setiap kelompoknya dengan suatu aturan khusus. Pada tahap mengajukan pertanyaan (questioning)

Pemilihan perpaduan NHT dan TGT mempuyai banyak keunggulan meskipun juga mempunyai kelemahan, selain itu kedua metode tersebut merupakan metode yang menekankan proses belajar pada siswa, atau student centered. Metode NHT merupakan salah satu pembelajaran aktif karena memberikan kesempatan kepada siswa untuk saling membagi ide-ide, mempertimbangkan jawaban yang paling tepat dan menjawab pertanyaan secara lisan sehingga menumbuhkan rasa percaya diri siswa dalam mengemukakan ide atau jawaban di muka kelas. Teknik juga mendorong siswa untuk meningkatkan semangat kerja siswa (Lie, 2004: 89). Selain itu, kombinasi model kooperatif tipe TGT dan NHT berdampak positif terhadap pengembangan karakter siswa seperti bersahabat, disiplin, kerja keras, dan kemandirian (Lepiyanto, 2012).

Bertitik tolak dari uraian di atas maka penelitian ini dilakukan dengan tujuan untuk mengetahui keefektifan penerapan kombinasi model pembelajaran kooperatif tipe TGT dan tipe NHT. 


\section{METODE PENELITIAN}

\section{Jenis dan Variabel Penelitian}

Penelitian ini termasuk jenis penelitian eksperimen semu (quasi experimental research) dengan variabel penelitian adalah keefektifan pembelajaran yang terdiri atas hasil belajar matematika, aktivitas siswa, dan respos siswa terhadap pembelajaran dengan kombinasi kooperatif tipe TGT dan tipe NHT. Desain penelitian ditunjukkan pada Tabel 1 sebagai berikut

Tabel 1. Model Desain Eksperimen

\begin{tabular}{|l|l|l|}
\hline $\mathrm{O}_{1}$ & $\mathrm{X}$ & $\mathrm{O}_{2}$ \\
\hline
\end{tabular}

Keterangan :

$\mathrm{O}_{1}=$ Pretest (observasi sebelum diterapkan perlakuan)

$\mathrm{X}=$ Treatment (pola perlakuan) yang berupa penerapan kombinasi model pembelajaran kooperatif tipe TGT dengan tipe NHT.

$\mathrm{O}_{2}=$ Posttest (observasi setelah penerapan perlakuan).

Populasi penelitian adalah semua siswa kelas XII IA SMAN 1 Pangsid pada semester ganjil tahun pelajaran 2016/2017. Sampel yang digunakan yaitu 28 orang siswa dipilih menggunakan teknik cluster random sampling.

Metode pengumpulan data yang digunakan dalam penelitian adalah: 1) Tes hasil belajar, digunakan untuk mengetahui prestasi belajar yang diperoleh siswa setelah mengikuti kegiatan pembelajaran kombinasi model kooperatif tipe TGT dan tipe NHT; 2) Observasi dengan menggunakan instrumen lembar observasi yang terdiri dari dua macam yaitu lembar aktivitas siswa untuk mengetahui aktivitas siswa dan lembar observasi keterlaksanaan model pembelajaran pada saat pembelajaran berlangsung; dan 3) Angket, digunakan untuk mengetahui respons siswa. Data yang telah diperoleh selanjutnya dianalisis menggunakan teknik analisis deskriptif dan inferensial.

\section{HASIL PENELITIAN}

Hasil penelitian yang dimaksud adalah hasil yang diperoleh pada analisis deskriptif dan inferensial. Data hasil belajar siswa, aktivitas siswa, hasil pengamatan keterlaksanaan aktivitas guru, dan hasil pengamatan respon siswa dianalisis dengan menggunakan statistik deskriptif. Selain itu, data hasil belajar siswa dianalisis dengan menggunakan analisis statistik inferensial.

\subsection{Hasil Analisis Statistika Deskriptif}

\section{1) Deskripsi Aktivitas Siswa}

Data aktivitas siswa diperoleh dari hasil pengamatan pada setiap pertemuan dengan menggunakan rubrik. Data yang diperoleh dari instrumen tersebut dirangkum pada setiap akhir pertemuan. Hasil rangkuman setiap observasi disajikan pada tabel berikut. 
Tabel 2. Rekapitulasi Hasil Observasi Aktivitas Siswa

\begin{tabular}{|c|c|c|c|c|c|c|c|c|c|}
\hline \multirow{2}{*}{ No } & \multirow{2}{*}{$\begin{array}{c}\text { Aspek } \\
\text { Aktivitas }\end{array}$} & \multicolumn{6}{|c|}{ Pertemuan ke- } & \multirow{2}{*}{$\begin{array}{r}\text { Rata- } \\
\text { Rata } \\
\end{array}$} & \multirow{2}{*}{ Kategori } \\
\hline & & $\mathrm{I}$ & II & IV & $\mathrm{V}$ & VII & VIII & & \\
\hline 1 & $\begin{array}{l}\text { Memperhatikan penjelasan } \\
\text { guru }\end{array}$ & 2 & 3 & 3 & 4 & 4 & 4 & 3.33333 & Baik \\
\hline 2 & $\begin{array}{l}\text { Membaca LKS dan buku } \\
\text { siswa }\end{array}$ & 3 & 3 & 4 & 4 & 4 & 4 & 3.66667 & Sangat baik \\
\hline 3 & Berdiskusi dalam kelompok & 3 & 3 & 3 & 4 & 4 & 4 & 3.5 & Baik \\
\hline 4 & Bertanya pada guru/ teman & 3 & 3 & 4 & 4 & 4 & 4 & 3.66667 & Sangat baik \\
\hline 5 & $\begin{array}{l}\text { Mengerjakan LKS/ tugas } \\
\text { secara berkelompok }\end{array}$ & 3 & 3 & 4 & 4 & 4 & 4 & 3.66667 & Sangat baik \\
\hline 6 & $\begin{array}{l}\text { Menyampaikan jawaban pada } \\
\text { guru dan teman di kelas } \\
\text { berdasarkan nomor yang } \\
\text { terpanggil pada saat games } \\
\text { dan tournament }\end{array}$ & 4 & 4 & 4 & 4 & 4 & 4 & 4 & Sangat baik \\
\hline \multirow[t]{3}{*}{7} & Menarik kesimpulan & 2 & 3 & 3 & 4 & 4 & 4 & 3.33333 & Sangat baik \\
\hline & Jumlah & 20 & 22 & 25 & 28 & 28 & 28 & 151 & \\
\hline & Rata-rata & 2.86 & 3.14 & 3.57 & 4 & 4 & 4 & 3.59524 & Baik \\
\hline
\end{tabular}

\section{2) Deskripsi Keterlaksanaan Aktivitas Guru}

Aktivitas guru yang diobservasi adalah aktivitas guru dalam mengelola pembelajaran yang menerapkan pembelajaran kombinasi model kooperatif tipe TGT dan tipe NHT. Adapun observasi terhadap aktivitas guru dalam penelitian ini mengacu pada Rencana Pelaksanaan Pembelajaran (RPP) yang terbagi atas tiga bagian utama yaitu: (1) Pendahuluan, (2) Inti, dan (3) Penutup.

Indikator yang digunakan untuk mengukur Tingkat Kemampuan Guru (TKG) dalam mengelola pembelajaran pada bagian pendahuluan adalah: (1) Mengecek pemahaman awal siswa, (2) Memotivasi siswa, (3) Menyampaikan tujuan pembelajaran yang akan dicapai.

Untuk kegiatan inti indikator yang digunakan adalah: (1) Menjelaskan kegiatan pembelajaran yang akan dilaksanakan, (2) Menjelaskan aktivitasaktivitas yang dilakukan siswa, (3) Mengorganisasikan siswa ke dalam kelompok-kelompok belajar, (4) Membimbing kelompok bekerja dan belajar, (5) Mengawasi setiap kelompok secara bergantian, (6) Memberi bantuan kepada kelompok/ individu yang mengalami kesulitan, (7) Memberi motivasi kepada kelompok untuk tetap bersemangat menyelesaikan tugasnya, (8) Menunjuk kelompok secara acak untuk mempresentasikan hasil kerja kelompoknya, (9) Mengadakan games dan tournament, dan (10) Memberikan penghargaan.

Sedangkan indikator pada kegiatan penutup adalah: (1) Membimbing siswa membuat rangkuman, (2) Memberikan tugas untuk dikerjakan di rumah, dan (3) Mengingatkan materi pada pertemuan berikutnya.

Hasil observasi terhadap aktivitas guru pada ketiga kegiatan di atas dalam proses pembelajaran dapat dilihat pada tabel berikut. 
Tabel 3. Hasil Observasi Aktivitas Guru dalam Pembelajaran

\begin{tabular}{ccccccccc}
\hline \multirow{2}{*}{$\begin{array}{c}\text { Perte- } \\
\text { Muan }\end{array}$} & Pendahuluan & TKG & Inti & TKG & Penutup & TKG & $\begin{array}{c}\text { Rata-Rata } \\
\text { TKG }\end{array}$ & Kriteria \\
\cline { 2 - 6 } I & 12 & 4 & 37 & 4.1 & 12 & 4 & 4.0 & Baik \\
II & 13 & 4.3 & 37 & 4.1 & 12 & 4 & 4.2 & Baik \\
III & 14 & 4.7 & 39 & 4.3 & 14 & 4.7 & 4.6 & Baik \\
IV & 14 & 4.7 & 39 & 4.3 & 14 & 4.7 & 4.6 & Sangat baik \\
\hline V & 14 & 4.7 & 40 & 4.4 & 14 & 4.7 & 4.6 & Sangat baik \\
\hline VI & 15 & 5 & 43 & 4.8 & 15 & 5 & 4.9 & Sangat baik \\
\hline VII & 14 & 4.7 & 40 & 4.4 & 14 & 4.7 & 4.6 & Baik \\
VIII & 15 & 5 & 40 & 4.4 & 14 & 4.7 & 4.7 & Sangat baik \\
\hline IX & 15 & 5 & 43 & 4.8 & 15 & 5 & 4.9 & Sangat baik \\
\hline Rata-rata & & $\mathbf{4 . 7}$ & & $\mathbf{4 . 4}$ & & $\mathbf{4 . 5 9}$ & $\mathbf{4 . 6}$ & Sangat baik \\
\hline-9
\end{tabular}

\section{3) Deskripsi Respon Siswa}

Berdasarkan jawaban siswa yang tertuang dalam angket respons siswa terhadap kegiatan pemebelajaran kombinasi model kooperatif tipe TGT dan
NHT meliputi pendapat dan perasaan siswa mengenai LKS, buku siswa, cara mengajar guru, dan suasana belajar.

Tabel 4. Persentase Respon Siswa

\begin{tabular}{|c|c|c|c|}
\hline No. & Aspek yang Direspon & \multicolumn{2}{|c|}{ Respon Siswa } \\
\hline \multirow[t]{2}{*}{1} & \multirow{2}{*}{$\begin{array}{l}\text { Apakah kamu merasa senang atau tidak senang selama mengikuti } \\
\text { pembelajaran ini? }\end{array}$} & Senang & Tidak Senang \\
\hline & & $100,0 \%$ & $0,0 \%$ \\
\hline \multirow[t]{3}{*}{2} & $\begin{array}{l}\text { Apakah kamu merasa senang atau tidak senang terhadap } \\
\text { komponen pembelajaran berikut? }\end{array}$ & Senang & Tidak Senang \\
\hline & a. Suasana pembelajaran di kelas & $100,0 \%$ & $0,0 \%$ \\
\hline & b. Cara mengajar guru & $100,0 \%$ & $0,0 \%$ \\
\hline \multirow[t]{5}{*}{3} & $\begin{array}{l}\text { Apakah komponen pembelajaran berikut ini baru atau tidak baru } \\
\text { bagi anda? }\end{array}$ & Baru & Tidak Baru \\
\hline & a. Lembar kegiatan Siswa (LKS) & $78,57 \%$ & $21,43 \%$ \\
\hline & b. Buku Siswa & $100,0 \%$ & $0,0 \%$ \\
\hline & c. Suasana Pembelajaran di Kelas & $100,0 \%$ & $0,0 \%$ \\
\hline & d. Cara mengajar Guru & $89,29 \%$ & $10,71 \%$ \\
\hline \multirow[t]{4}{*}{4} & $\begin{array}{l}\text { Apakah bahasa yang digunakan pada komponen pembelajaran } \\
\text { berikut jelas atau tidak jelas? }\end{array}$ & Jelas & Tidak Jelas \\
\hline & a. Lembar kegiatan Siswa (LKS) & $85,71 \%$ & $14,29 \%$ \\
\hline & b. Buku Siswa & $85,71 \%$ & $14,29 \%$ \\
\hline & c. Cara mengajar Guru & $96,43 \%$ & $3,57 \%$ \\
\hline 5 & $\begin{array}{l}\text { Apakah penampilan (tulisan, ilustrasi/gambar dan letak gambar) } \\
\text { komponen pembelajaran berikut menarik atau tidak menarik }\end{array}$ & Menarik & Tidak menarik \\
\hline
\end{tabular}


Jurnal Edumaspul, 1 (2), Oktober 2017 - 30

Putriyani S.

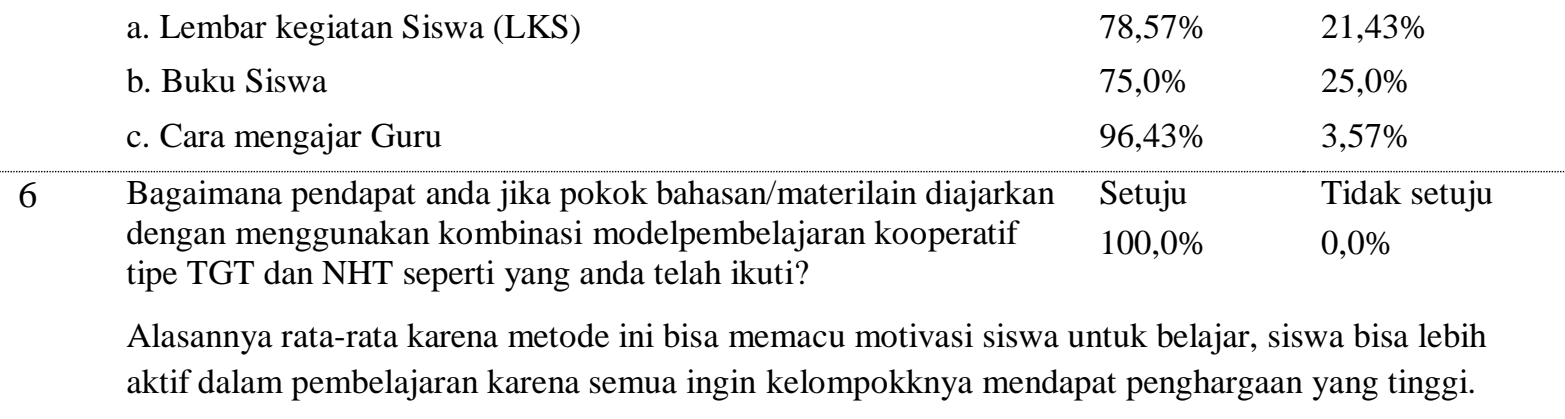

\section{4) Deskripsi Hasil Belajar Siswa}

Hasil belajar siswa pada penelitian ini dideskripsikan berdasarkan analisis awal (pretest) dan tes akhir (posttest). Adapun klasifikasi peningkatan hasil belajar siswa disajikan pada tabel berikut.

Tabel 5. Rekapitulasi Hasil Belajar Siswa

\begin{tabular}{lcc} 
& Pretest & Posttest \\
Ukuran sampel & 28 & 28 \\
\hline Mean & 33,75 & 83,04 \\
\hline Median & 30 & 85 \\
\hline Modus & 30 & 90 \\
\hline Deviasi standar & 8,89 & 9,75 \\
\hline Nilai tertinggi & 50 & 100 \\
\hline Nilai terendah & 20 & 60 \\
\hline
\end{tabular}

Tabel 6. Klasifikasi Gain Ternormalisasi

\begin{tabular}{cccc}
\hline Koefisien Normalisasi Gain & Jumlah Siswa & Persentase $(\%)$ & Klasifikasi \\
\hline $\mathrm{g}<0,3$ & 0 & 0,00 & Rendah \\
$0,3 \leq \mathrm{g}<0,7$ & 9 & 32,14 & Sedang \\
$\mathrm{g} \geq 0,7$ & 19 & 67,86 & Tinggi \\
\hline Rata-rata & & 0,76 & Tinggi \\
\hline
\end{tabular}

Selanjutnya kategori kemampuan pretest dan posttest pada kelas eksprimen disajikan pada tabel berikut: 
Tabel 7. Distribusi Frekuensi Tingkat Kemampuan Siswa

\begin{tabular}{|c|c|c|c|c|c|}
\hline \multirow{2}{*}{ Interval } & \multirow{2}{*}{$\begin{array}{c}\text { Kategori } \\
\text { Penguasaan Siswa }\end{array}$} & \multicolumn{2}{|c|}{ Pretest } & \multicolumn{2}{|c|}{ Posttest } \\
\hline & & Frekuensi & Persentase(\%) & Frekuensi & Persentase $(\%)$ \\
\hline $90-100$ & Sangat tinggi & 0 & 0 & 11 & 39,29 \\
\hline $80-89$ & Tinggi & 0 & 0 & 8 & 28,57 \\
\hline $65-79$ & Sedang & 0 & 0 & 8 & 28,57 \\
\hline $55-64$ & Rendah & 0 & 0 & 1 & 3,57 \\
\hline \multirow[t]{2}{*}{$0-54$} & Sangat rendah & 28 & 100 & 0 & 0 \\
\hline & Jumlah & 28 & 100 & 28 & 100 \\
\hline
\end{tabular}

Tingkat pencapaian ketuntasan hasil belajar matematika secara klasikal pada kelas yang diajar dengan kombinasi model kooperatif tipe TGT dan tipe NHT dapat dilihat pada tabel berikut.

Tabel 8. Distribusi Ketuntasan Hasil Belajar Siswa

\begin{tabular}{cccc} 
& \multirow{2}{*}{ KKM } & \multicolumn{2}{c}{ Persentase Ketuntasan Klasikal(\%) } \\
\cline { 3 - 4 } & & Tuntas & Tidak tuntas \\
\hline Pretest & \multirow{2}{*}{70} & 0 & 100 \\
Posttest & & 96,43 & 3,57 \\
\hline
\end{tabular}

\subsection{Hasil Analisis Statistika Deskriptif}

1. Pengujian peningkatan hasil belajar siswa sebelum tindakan (pretest) dan hasil belajar siswa setelah tindakan (posttest).

Berdasarkan hasil analisis data hasil belajar diperoleh nilai $t=$ 38,550 dengan $d f=27$. Karena nilai $p$ $=0,00<0,05$ menunjukkan bahwa ada perbedaan yang signifikan antara hasil belajar pada pretest dan posttest.

2. Pengujian rata-rata hasil belajar siswa pada posttest terhadap KKM

Berdasarkan hasil analisis data hasil belajar diperoleh nilai $t=7,074$ dengan $d f=27$. Karena nilai $p=0,00$ $<0,05$ menunjukkan bahwa rata-rata hasil belajar siswa setelah diajar dengan metode pembelajaran kombinasi model kooperatif tipe TGT dan tipe NHT lebih dari 70.

3. Pengujian rata-rata hasil gain ternomalisasi.

Hasil analisis yang diperoleh yaitu nilai $t=18,882$ dengan $d f=27$. Karena nilai $p=0,00<0,05$ menunjukkan bahwa rata-rata gain ternormalisasi yang diajar dengan pembelajaran kombinasi model kooperatif tipe TGT dan tipe NHT lebih dari 0,3 .

Berdasarkan hasil analisis deskriptif dan inferensial yang telah diuraikan sebelumnya, tampak bahwa kriteria keefektifan yang dipenuhi oleh pembelajaran kombinasi model kooperatif tipe TGT dan tipe NHT adalah hasil belajar siswa, aktivitas siswa, dan respons siswa. Oleh karena itu dapat dsisimpulkan bahwa pembelajaran kombinasi model 
kooperatif tipe TGT dan tipe NHT efektif untuk diterapkan di kelas XII IA SMAN 1 Pangsid.

\section{PEMBAHASAN}

\subsection{Hasil Pengamatan terhadap Aktivitas Siswa}

Berdasarkan data observasi aktivitas siswa pada Tabel 2, tampak bahwa aktivitas siswa berada pada kategori baik. Dengan demikian dapat disimpulkan bahwa aktivitas siswa pada kelas eksprimen secara deskriptif memenuhi kriteria keefektifan. Hal tersebut menandakan bahwa keaktifan siswa pada pembelajaran matematika melalui kombinasi model kooperatif tipe TGT dan NHTsangat baik. Siswa sangat antusias dalam mengikuti pembelajaran kooperatif dan menunjukkan aktivitas aktif dalam berinteraksi dalam kelompok.

Hasil pengamatan terhadap aktivitas siswa dalam pembelajaran kombinasi model kooperatif tipe TGT dan tipe NHT terlihat bahwa siswa tidak canggung dalam bekerjasama, saling memberi dan menerima, saling memberikan dukungan, serta menghargai pendapat orang lain. Hal ini disebabkan karena sebelum pelaksanaan pembelajaran siswa diberi pemahaman tentang keterampilan kooperatif sehingga siswa dapat memahami dengan baik fase-fase dari pembelajaran kooperatif kombinasi model kooperatif tipe TGT dan tipe NHT.

\subsection{Hasil Pengamatan terhadap Aktivitas Guru}

Berdasarkan hasil penelitian pada aspek ketercapaian aktivitas guru, diperoleh bahwa skor rata-rata ketercapaian aktivitas guru dalam mengelola pembelajaran adalah 4,6 berada pada kategori terlaksana dengan sangat baik. Ketercapaian aktivitas guru mulai dari pertemuan pertama sampai terakhir mengalami peningkatan. Ini disebabkan karena pada setiap akhir pertemuan dilakukan diskusi-diskusi dengan pengamat tentang kekurangan-kekurangan yang dilakukan oleh guru. Hal ini memungkinkan untuk memperbaiki penampilan guru pada pertemuanpertemuan berikutnya dengan memperhatikan aspek-aspek yang dinilai kurang pada pertemuan sebelumnya. Hasil analisis data pengamatan terhadap kemampuan guru dalam mengelola pembelajaran secara keseluruhan menunjukkan tiap aspek memenuhi kriteria keefektifan dan berada pada kategori sangat baik. Ini berarti keterlaksanaan model pembelajaran berada pada kategori terlaksana dengan sangat baik.

\subsection{Hasil Pengamatan terhadap Respon Siswa}

Berdasarkan hasil angket respon siswa, sebanyak $91,84 \%$ siswa yang merespon pernyataan positif pada pembelajaran kombinasi model kooperatif tipe TGT dan tipe NHT. Perolehan respon siswa telah memenuhi kriteria keefektifan yaitu rata-rata persentase respon siswa setiap aspek berada pada kategori $\geq 75 \%$. Artinya hampir seluruh siswa memberikan respon positif terhadap pembelajaran kombinasi model kooperatif tipe TGT dan tipe NHT.

Dengan adanya minat siswa yang besar dalam kegiatan pembelajaran akan berpengaruh kepada peningkatan motivasi belajar siswa dan pada akhirnya akan berpengaruh pula terhadap hasil belajar siswa. Mereka merasa bahwa belajar melalui kelompok kooperatif menjadi konsep yang dipelajari lebih muda dipahami dan diingat. Rata-rata komentar tertulis mengatakan senang terhadap proses pembelajaran dengan alasan metode ini bisa memacu motivasi siswa untuk 
belajar, siswa lebih aktif dalam pembelajaran karena semua ingin kelompoknya mendapat penghargaan yang tinggi dan ingin jika metode ini diterapkan pada materi lain.

\subsection{Hasil Belajar Siswa}

Berdasarkan data hasil belajar pada pretest terlihat bahwa pada nilai mean 33,75 , median 30 dan modus 30 menunjukkan bahwa sekitar $50 \%$ siswa memperoleh nilai dibawah 30 sedangkan pada posttest terlihat bahwa nilai mean 83,04 , median 85 dan modus 90 menunjukkan bahwa sekitar 50\% siswa memperoleh nilai diatas 85 .

Standar deviasi pretest adalah 8,89 lebih kecil dari standar deviasi posttest yaitu 9,75 yang menunjukkan bahwa kemampuan siswa semakin bervariasi setelah diberikan pembelajaran kombinasi model kooperatif tipe TGT dan tipe NHT. Secara deskriptif dapat dikatakan bahwa kemampuan siswa pada kelas eksprimen menjadi lebih baik dari pada sebelum diberikan pembelajaran kombinasi model kooperatif tipe TGT dan tipe NHT.

Hasil pretest menunjukkan bahwa hasil belajar siswa tergolong dalam kategori sangat rendah dimana 28 orang siswa memperoleh nilai pada interval $0-$ 54. Setelah diberikan perlakuan, hasil belajar (posttest) 39,29\% atau 11 orang berada pada kategori 90 - 100 atau sangat tinggi dan $28,57 \%$ siswa berada pada kategori tinggi. Ini berarti bahwa siswa telah memahami materi setelah pembelajaran kombinasi model kooperatif tipe TGT dan tipe NHT.

Berdasarkan pada nilai KKM nilai hasil belajar siswa yang mencapai kriteria ketuntasan sebanyak 27 orang siswa atau $96,43 \%$. Nilai hasil belajar siswa tertinggi adalah 100, nilai terendah 60 dan deviasi standarnya adalah 9,75 dengan nilai ratarata 83,04. Hal ini menunjukkan bahwa pembelajaran kooperatif dalam $\begin{array}{lcr}\text { pembelajaran } & \text { telah } & \text { banyak } \\ \text { menyumbangkan } & \text { kontribusi } & \text { dalam } \\ \text { meningkatkan hasil belajar siswa. } & \end{array}$

\section{KESIMPULAN DAN SARAN}

\subsection{Kesimpulan}

Pembelajaran matematika melalui penerapan model kooperatif tipe TGT dan NHT dinyatakan efektif sebab memenuhi tiga indikator keefektifan yaitu: (1) Aktivitas siswa, (2) Aktivitas Guru, (3) Respon siswa terhadap pembelajaran dengan kombinasi kooperatif tipe TGT dan tipe NHT, dan (4) Hasil belajar matematika siswa.

1. Aktivitas siswa berada pada kategori baik.

2. Aktivitas guru berada pada kategori sangat baik.

3. Respon siswa terhadap pembelajaran adalah positif..

4. Hasil belajar siswa memenuhi kriteria efektif yang ditandai dengan rata-rata nilai hasil belajar siswa 83,04 (KKM = 70) dan peningkatan hasil belajar matematika siswa berada pada nilai gain di atas 0,30 serta ketuntasan secara klasikal adalah 96,43\%.

\subsection{Saran}

Berdasarkan kesimpulan yang dikemukakan di atas, maka diajukan saran sebagai berikut: (1) Dalam melaksanakan pembelajaran guru hendaknya mampu memilih pendekatan pembelajarn yang efektif, yang selalu melibatkan siswa secara aktif sehingga materi pelajaran akan mudah diterima oleh siswa, dan (2) Pembelajaran matematika melalui kombinasi model kooperatif tipe TGT dan tipe NHT perlu mendapat pertimbangan oleh guru matematika sebagai sarana untuk meningkatkan prestasi belajar siswa. 


\section{DAFTAR PUSTAKA}

[1] Adeyemi, B. 2008. Effect Cooperative Learning and Problem Solving Strategies on Junior Secondary School Students Achievement in Social Studies. Electronic Journal of Research in Educational Psycology, Vol. 6, No.3, pp 691-708

[2] Annurwanda, P., Mardiyana, \& Saputro, D.R.S. 2014. Eksperimentasi Model Pembelajaran Kooperatif Tipe Teams Games Tournaments dan Team Assisted Individualization pada Materi Garis dan Sudut Ditinjau dari Kecerdasan Emosional Siswa Kelas VII SMP Negeri Se-Kabupaten Magetan Tahun Pelajaran 2013/2014. JMEE, Volume IV Nomor 2, Desember 2014.

[3] Ballantine, J. \& Larres, P. 2007. Cooperative Learning: A Pedagogy to Improve Students Generic Skills. Journal Articles; Report-Evaluative Aducation \& Training, Vol. 49, No. 2, pp 126-137.

[4] Bas, G. \& Beyhan, O. 2010. Effect of Multiple Intelligence Supported Project-Based Learning on Student's Achievement Levels and Attitude Toward Anglish Lesson. International Electronic Journal of Elementary Education, Vol. 2, No. 3, pp 365-385.

[5] Charlton, B., Williams, R. L dan McLaughlin, T.F. 2005. Educational Games: A Technique to Accelerate the Acquisition of Reading Skills of Children with Learning Disabilities. International Journal of Special Education, Volume 20, Number 2, page 66-72.

[6] Doymus, K. 2007. Effect of Cooperative Learning Strategy and Learning Phases of Matter and One Component Phase Diagrams. Journal of Chemical Education, Vol. 84, No. 11, pp 1857-1860.
[7] Fuad, Moh. Nasrul. 2009. Meningkatkan Motivasi dan Hasil Belajar Persamaan Garis Lurus Siswa Kelas VIII Melalui Penerapan Model Pembelajaran Kooperatif Tipe NHT (Numbered Heads Together). Skripsi tidak diterbitkan. Malang: FMIPA Universitas Negeri Malang.

[8] Goos, M. 2004. Learning Mathematics in a Classroom Community of Inquiry. Journal of Research of Mathematics Education, Vol. 35, No.4, pp 258- 291.

[9] Iriana, Tanjung, M. 2010. Penerapan Model Pembelajaran Kooperatif Numbered Head Together (NHT) untuk Meningkatkan Prestasi Belajar Siswa Kelas XI IPA di SMA Negeri 1 Kepanjen, (Online), (http://library.um.ac.id/ptk/index.php? mod=detail\&id=45412), diakses 15 Oktober 2016.

[10] Kahfi, S. 2004. Pembelajaran Kooperatif dan Pelaksanaannya dalam Pembelajaran Matematika. Jakarta: Depdiknas

[11] Lai, C. H., She, Y. X., Sung, C. Y., and Jong, B. S. 2012. The GameBased Learning of Combining Competition and Cooperative Learning. Computers \& Education, vol 57(1), pp 1127-1136.

[12] Lepiyanto, A. 2012. Implementasi Lesson Study pada Metode Numbered Heads Together Dipadu dengan Team Games Tournament untuk Pengembangan Karakter Siswa Kelas X SMA Negeri 1 Kepanjen. Bioedukasi, Volume 3 Nomor 2 , Nopember 2012.

[13] Lie, A. 2004. Cooperatif learning: Mempraktekkan Cooperatif Learning di Ruang-Ruang Kelas. Jakarta: Pt. Raja Widia Sarana Indonesia.

[14] Purnamasari, Yanti. 2013. Pengaruh Model Pembelajaran Kooperatif Tipe Teams Games-Tournament (TGT) Terhadap Kemandirian Belajar dan 
Peningkatan Kemampuan Penalaran dan Koneksi Matematik Peserta Didik SMPN 1 Kota Tasikmalaya. Tesis tidak diterbitkan. Jakarta. PPS Universitas Terbuka.

[15] Rahmi. 2008. Model Pembelajaran Kooperatif Tipe Numbered Head Together (NHT) Sebagai Upaya Meningkatkan Pemahaman Siswa dalam Matematika. Jurnal Percikan, Volume 89:87.

[16] Slavin, R.E. 2008. Cooperative Learning Teori, Riset dan Praktik. Terjemahan: Nurulita Yusron. Bandung: Nusa Media

[17] Smith-Stoner, M. \& Molle, M.E. 2010. Collaborative Action Research: Implementation of Cooperative Learning. The Journal of Nursing Education, Vol. 49, No. 6, pp 312318.
[18] Solikhah, Budiyono, \& Saputro. 2014. Eksperimentasi Model Pembelajaran Kooperatif Tipe Group Investigation (GI) dan Numbered Heads Together (NHT) pada Materi Garis Singgung Lingkaran Ditinjau dari Kecerdasan Majemuk Siswa Kelas VIII SMP Negeri Se-Kota Madiun Tahun Ajaran 2013/2014. Jurnal Elektronik Pembelajaran Matematika, Vol.2, No.7, hal 727-739, September 2014. 